\title{
META ANALYSIS: ANXIETY DISORDER TOWARD COVID-19 PANDEMIC IN PREGNANT WOMEN
}

\author{
Alfi Makrifatul Azizah'), Yulia Lanti Retno Dewi²), Bhisma Murti') \\ ${ }^{1)}$ Masters Program in Public Health, Universitas Sebelas Maret \\ ${ }^{2)}$ Faculty of Medicine, Universitas Sebelas Maret
}

\begin{abstract}
Background: The COVID-19 pandemic and related restrictions substantially altered daily lives of pregnant women, exaggerating the prevalence of anxiety compared with the pre-COVID-19 studies. The purpose of this study was to investigate anxiety disorder toward covid-19 pandemic in pregnant women.

Subjects and Method: This was a systematic review and meta-analysis. Using the PubMed and Google Scholar database, a literature search was conducted for crosssectional full-text studies on the effect of COVID-19 pandemic on anxiety in pregnant women. The following search terms were used: "COVID-19" AND "pregnancy" AND "Anxiety". Eligibility criteria were defined using the PICO model as follows, (1) population: pregnant women, (2) intervention: COVID-19 pandemic, (3) comparison: non pandemic, and (4) outcome: anxiety. The systematic review was carried out according to the PRISMA guidelines. Data analysis were performed using RevMan 5.3.

Results: There were 6 studies from Iran, China, and United States involved for metaanalysis. This study showed that COVID-19 pandemic increased anxiety in pregnant women 2.59 times than non pandemic $(\mathrm{OR}=2.59 ; 95 \% \mathrm{CI}=1.95$ to $3.45 ; \mathrm{p}<0.001)$.

Conclusion: COVID-19 pandemic increases anxiety in pregnant women.
\end{abstract}

Keywords: COVID-19 pandemic, anxiety, pregnant mothers

Correspondence:

Alfi Makrifatul Azizah. Masters Program in Public Health, Universitas Sebelas Maret. Jl. Ir. Sutami 36A, Surakarta 57126, Central Java. Email: alfimakrifatulazizahh@gmail.com. Mobile: 085375335480. 